\title{
The Government's Role in the Protecting The Principle Freedom of Contract in Employment Contracts
}

\author{
Masitah Pohan ${ }^{1}$, Tan Kamello ${ }^{2}$, Suhaidi ${ }^{3}$, Syafruddin Kalo ${ }^{4}$ \\ ${ }^{1}$ Doctoral Student of Universitas Sumatera Utara, Indonesia ${ }^{2,3}{ }^{4}$ Professor at Universitas Sumatera Utara, \\ Indonesia
}

\begin{abstract}
The principle of freedom of contract to be regarded as a basic principle of contract formation but could be legal problems if it does not protect the weak party. In the employment contract, the bargaining position between businessmen and workers are not always balanced. Strong bargaining position between businessmen and workers depend on the position of the ability of the parties to the negotiations. For workers who do not have the education, expertise, skills and experience then the employer has a weak bargaining position so just accept what the conditions, rights, obligations, and procedures in the employment agreement previously set by the business / employer. The employment agreement without bargaining is caused by high unemployment, as a result of very low employment rate and the low quality of labor. This article investigate the role of government in protecting workers who have a weak bargaining position through legislation, labor inspection and affirmative action.
\end{abstract}

Keywords - affirmative action, employment contract, freedom on contract, government, manpower

\section{INTRODUCTION}

Freedom of contract in employment contracts raises controversial issues. On the one hand there is a labor agreement that is based on freedom of contract through a bidding process (negotiations) between workers and businesses and on the other hand there is a labor agreement that has been determined businesses without first bargaining process. The principle of pacta sunt servanda stating that the agreement made legally valid as legislation (Badrulzaman, 2001: 82) in accordance with Article 1338 paragraph (1) of the Civil Code "All approvals are made legally valid as law for those who make it", By the term legally legislators showed that making the agreement must meet the requirements specified in accordance with Article 1320 of the Civil Code.

Applicability of the consensualism principle of the law of treaties Indonesia according to solidify the principle of freedom of contract. Without the agreement of one of the parties make an agreement, then the agreement made not to the effective even be canceled. Coercion indicates the absence of agreement that may be performed by the other party to provide an option to him, namely to agree bound by a treaty referred to, or reject bound by a treaty with the desired result of the transaction do not materialize (take it or leave it). A person is free to make agreements with any party that wished. Act only regulates certain people are not competent to make an appointment, According to Article 1330 of the Civil Code, minors and people were put under the forgiveness not have the capacity to make an appointment.

The development of the doctrine of laissez faire economic thought of freedom of contract into a general principle in favor of free competition. Freedom of contract becomes the embodiment of law (legal expression) the principle of the free market (Ridwan Khairandy, 2003: 1). If no state intervention in the contract is contrary to the principles of the free market (Horwtiz J. Morton, 1992: 3). Even freedom of contract towards freedom without limits. Those principles had been developed and the shift caused by: first, the growth of standard contract forms; second, reduced the meaning of freedom and the will of the parties, as a result of widespread government interference in people's lives; Third, the inclusion of the consumer as the contracting party (Atiyah, 1983: 33). All three of these factors relate to each other. The principle of freedom of contract and freedom to choose is still seen as the basic principles of contract formation, which is based on Pancasila as the basic principle of Indonesia.

Before the nineteenth century, the contract is an expression of human freedom (individually) to select and enter into agreement. The contract is a form of freedom (freedom of contract) and the free will to choose (freedom of choice). Restrictions on the principle of freedom of contract can also be concluded through Article 1338 paragraph (3) which states that an agreement is only carried out in good faith. Therefore, the parties are not able to determine its own course clauses contained in the agreement but it should be based and carried out in good faith. Agreements based on bad faith, for example fraud with a legal effect of the agreement can be canceled (Herlien Budiono, 2010: 98). 
Free option for someone to do essentially adopted binding agreements also in the employment agreement. Freedom obtained through the right person, given the limitations with legally binding in the form of liabilities. Civil law provides authority-the authority on the one hand and on the other hand, it imposes obligations, the fulfillment of which if necessary can be enforced with the help of a ruler (H.F.A. Vollmar, 1996: 2). For civil law also gives the norms that are based on fairness and decency. A balanced position between businesses and workers are not always being met because of the strong tend to dominate the weaker position (Zainal Asikin Kusuma Atmaja, 1993: 367). Then, in the twentieth century raised various criticisms and objections to the freedom of contract with regard to the negative consequences thereof. At the end of freedom of contract is shifting toward a paradigm of propriety, even though freedom of contact is still a vital principle in contract law both in civil law and common law (Peter de Cruz, 1993: 183-185). But unlike the freedom of contract that developed in the nineteenth century. Now the freedom of contract is not freedom without limits. Strong bargaining position depends on the position of the ability of the parties to the negotiations. Workers who have the criteria of ability education, ability, skill, experience a rare and needed by businesses will have better bargaining power is high, for negotiations regarding content, timing, and the types listed in the employment agreement (Peters and Koesriani Siswosoebroto, 1990: 69).

Business / employers recruiting workers willing to approve the employment agreement based on the basic provisions established unilaterally businesses. Workers just accept what the conditions, rights, obligations, and procedures in the employment agreement previously set by the business / employer. The employment agreement without bargaining is caused by high unemployment, as a result of very low employment rate and the low quality of labor. Talking about the legal protection of the workers must be started from the understanding of the relationship between workers and employers. In labor-employer relations worker position is always subordinate to the employer. This is due to an imbalance of economic power inherent in labor and employer. Sociologically because labor is not free. As a person who has no other life provision of the energy, he was forced to work for others. And the employer is that basically determine the terms of employment.

In Indonesia there are some obstacles in labor law enforcement, because of legal uncertainty and lack of clarity in the rules of law. Perception of freedom of contract law is based on the provisions of Law No. 13 of 2003 on Manpower. On the other hand, the shift in the perspective of freedom of contract or standard contract as a form of efficiency has eliminated the right of either party happens in binding labor agreements, particularly in the fair and proper treatment in law employment relationship for the worker. There are two theories of industrial relations that is Corporatist Model or Regulatory Model. The first model has a characteristic, that the parties involved in the employment relationship are given the autonomy to determine the terms of employment and working conditions themselves. Here, government intervention is not so dominant. The second model has a characteristic, the parties to the employment relationship is hardly given the autonomy to determine the terms of employment or working conditions. Here the government to intervene dominant. Interference of the state in the areas of labor done through employment law regulations to reflect state policy. State policy is a set of actions defined and implemented or not implemented by the government which has the purpose or goal-oriented in the interest of the entire community. Thus the purpose and orientation of employment law regulations is in the interest of working people (Supriyanto Day, 2006: 147).

Industry dynamics appear to have three context of labor relations, namely unitarian, pluralist and Marxian. "In the context of the Unitarian, the conflict between labor and business is seen as a phenomenon of irrational, otherwise the cooperation between workers and businessmen believed to be a state of" normal ", in which the running of the company guided by organizational efficiency and rationality of management. Labor costs are not relevant to the expense of disputes between workers and businesses, even the wages did not become an important variable and shaping the social structure of the industry. Workers continue to develop harmonious relationships with the company despite the lower and higher wages. The company will increase the company's profits if wages rise without being affected by the regulation on salary level. As a result of the context of this unitarian, trade unions be helped to lose meaning (Day Supriyanto, 2006: 149). In the context of a pluralist, here encountered a conflict between workers and businesses, but always be resolved by way of mutual accommodate each other's interests and mutual benefit. This context of provision of space to organize for workers and their more equitable sharing of benefits, will reduce the quality and quantity of conflicts that may arise between workers and entrepreneurs. Labor unions have a major significance as a means of labor for the interests of workers and their families. Marxian context basing on Marx's analysis that focused on the injustice hidden core of public relations in the capitalistic economic system where he sees the relationship is exploitative (Supriyanto Day, 2006: 150).

Civil law is a subsystem of the national law as a legal parent treaty must refer to Pancasila as the philosophical foundation and the Constitution of the Republic of Indonesia Year 1945 as the constitutional basis. Developing laws do patchwork, because they do not have a clear strategic direction and continuity of direction and purpose. In this case, the development of labor law at the role of government in order to be sustainable development of manpower law. 


\section{THE ROLE OF GOVERNMENT BASED ON MANPOWER LAW}

Role of Government becomes one of the key in many matters relating to employment. Law No 13 Year 2003 on Manpower describes 18 Government's role in employment, namely:

1. Planning of Labor and Employment Information. Governments set policy and develop manpower planning on an ongoing basis which includes workforce planning Macro and Micro manpower planning as well as compiled on the basis of manpower information, which includes population and labor force, employment, job training including job competence, labor productivity, relationships industrial, working conditions, wages and labor welfare and social security.

2. Job Training. Job training and directed to provide, improve, and develop job competence in order to improve the capability, productivity, and well-being with regard to labor market needs and the business world, both inside and outside the working relationship is conducted based training programs that refer to job competence standards and can be done in stages. Job training organized by the training institutions of government work and / or private vocational training institutions and held in place or workplace training as well as to cooperate with the private sector. Central Government and / or the Local Government fostering job training and apprenticeship directed towards improving the relevance, quality, and efficiency of vocational training and productivity is done through the development of productive culture, work ethics, technology, and efficiency of economic activities towards the realization of national productivity,

3. Employment. Every worker has the same rights and opportunities to choose, obtain, or changed jobs and earn a decent income inside or outside the country. Job placement is implemented based on the principle of open, free, objective, and fair and equal opportunity without discrimination. Job placement is directed to place workers in the right position according to the expertise, skills, talents, interests, and abilities with regard dignity, dignity, human rights and legal protections are carried out with due regard to equal employment opportunities and labor supply in accordance with the needs of national and regional programs. Employers who need to recruit its own workforce manpower needed or through implementing employment. Implementing this employment must provide protection from recruitment to employment which includes welfare, safety and health, both mental and physical labor.

4. Expansion of Employment Opportunities. The government is responsible to seek expansion of employment opportunities both within and outside the employment relationship in a way together with the community to seek expansion of employment opportunities both within and outside the employment relationship. All policies both central and local government in every sector directed to realize the expansion of employment opportunities both within and outside the employment relationship.

5. Tackling Child Labor Affairs Labor Relations. The government is obliged to address the problem of children who work outside the employment relationship and set through government regulation.

6. Establish the Wage Policy To Protect Workers. Every worker / laborer is entitled to earn a living befitting meet humanity. To realize the income that meets a decent livelihood for humanity as intended, the government set a wage policy that protects workers which covering minimum wage, overtime, wages do not work due to absent, wages do not work due to other activities outside of work, wages for exercising the right to take a rest, form and manner of payment of wages, fines and deductions from wages, things that can be calculated with a wage structure and scale proportional wages, wages for severance payments and wages for income tax calculation.

7. Facilitate Efforts Productive Workers. To improve the welfare of workers / laborers, formed cooperative workers / labor and productive efforts in the company. Governments, businesses, and workers / laborers or union / labor union seeks to cultivate cooperative workers / laborers, and develop productive activities as intended. The formation of cooperatives as intended, implemented in accordance with the legislation in force. Efforts to cultivate cooperative workers / laborers as mentioned, is regulated by the Government.

8. Establish Policy and Providing Services. In the conduct of industrial relations, the government has the function to set the policy, provide services, conduct surveillance, and take actions against violations of labor legislation. In the conduct of industrial relations, workers / laborers and union / labor union has the function of carrying out the work in accordance with its obligations, to maintain order in the continuity of production, in a democratic aspirations, develop their skills and expertise and helping promote the company and fight for the welfare of members and their families. In the conduct of industrial relations, business and organizational business actors has the function of creating partnerships, develop the business, expanding employment, and provide welfare workers / laborers in an open, democratic, and fair.

9. Facilitate Settlement of Industrial Relations. Industrial Relations carried out by means of trade unions / labor unions, businesses organizations, cooperation agencies bipartite, tripartite cooperation institution, company regulations, collective labor agreements, labor laws and industrial relations dispute resolution institutions.

10. Endorses the Company Regulations and Collective Labor Agreement. Ratification of company regulations by the Minister or his representative must be given within a period of 30 (thirty) days after the company 
received regulatory texts. When regulations the company has met the requirements, within 30 (thirty) days is exceeded and regulation of companies not yet been legalized or appointed official, the company's rules considered was approved.

11. Monitoring and Enforcement of Labor. In realizing the implementation of the rights and obligations of workers / laborers and entrepreneurs, the government must carry out supervision and enforcement of labor legislation. Implementation of labor legislation in the realization of industrial relations are the responsibility of the worker / laborer, businesses, and governments.

12. Receive Strike Notice. At least within seven working days before the strike carried out, workers / laborers and trade unions / labor unions shall notify in writing to businesses and government agency responsible for manpower affairs.

13. Mediates Talks In Strike. Before and during the strike, the responsible agency in the field of labor required to resolve the problem that causes the strike by bringing and negotiating together with the disputing parties. In the event that the negotiations referred to an agreement, it must be made a joint agreement signed by the parties and employees of the government agency responsible for labor affairs as a witness.

14. Anticipating the occurrence of Termination. Business, workers / unions / labor unions, and the government must make all efforts in order to prevent termination of employment. In terms of effort has been made, but the layoffs can't be avoided, the purpose of termination of employment agreement shall be negotiated by the business and trade / labor union or the employees / workers if the worker / laborer shall not be members of trade unions / labor, In the discussion as mentioned really do not produce an agreement, businesses can only terminate the employment of workers / laborers after obtaining the determination of a labor dispute resolution body. Determining application termination be submitted in writing to the institution in resolving industrial disputes and the reasons which it is based.

15. Conduct Guidance. Government to provide guidance to the elements and activities related to employment with the organization to include businesses, trade unions / labor unions, and related professional organizations and implemented in an integrated and coordinated.

16. Conduct Supervision. Labor inspection carried out by labor inspectors who are competent and independent to ensure the implementation of labor laws and regulations set by the Minister or his representative. Labor inspection carried out by a separate working unit of the agency whose scope of duties and responsibilities in the field of employment in the central government, provincial government and district / city governments are regulated by Presidential Decree.

17. Conducting Investigations. Inspectors be given special authority as investigators civil servants in accordance with the legislation in force.

18. Socialization Employment Rules. Socialization employment rules is implemented in ways that more could touch all the components. Workers and businesses must know the rules of employment to minimize violations. The function and role of government in promoting employment rules is expected to be an alternative preventive balanced.

\section{THE ROLE OF GOVERNMENT IN MANPOWER CONTROL}

Self-government embodied by the system of regional autonomy which was originally centralized to decentralized. Understanding Regional autonomy is a right, authority, and duties of the autonomous regions to set up and manage their own affairs and interests of the local community government in accordance with law. Manage and organize itself does not then be interpreted freely and become the prerogative of the regent / mayor simply because of the substance of autonomy is also how service to the community is not neglected, including the ministry of labor issues (Abdul Khakim, 2010: 38). Everything of course there are always pluses and minuses, including the implementation of regional autonomy. Already a logical consequence that any change of policy, will have an impact or barriers. It thus also occur in the employment field.

Some of the problems related to the autonomy of government policy in the areas of employment, among others: First, where sometimes some policy regent / mayor is also governor, who put technical personnel in the field of employment is not in accordance with the required competencies. The principle of "the right man on the right place" is ignored. Even sometimes apparatus that has ever received technical training the workforce should be moved to the fields / other parts for various reasons while the officials who did not have competence in midwifery manpower in place of employment, in which requires legal and technical competence. In fact, they are expected to provide good service to the community. Giving more powers to the regions is to provide better services to the people, in order to provide better services necessary to increase capacity of government officials in the area. To keep in mind that the employment problem is not limited to administration and management, but also regarding technical issues and laws so that officials technically placed in the field of employment is an absolute must understand the employment problem comprehensively, ranging from philosophical understanding of labor protection, the spirit of the legislation employment, to technical handling of labor dispute settlement, including an understanding of the strike (strike) and the closure of the company (lock out). How is it possible to 
provide better public services to the field of employment if the authorities have not or do not understand the spirit of labor in a comprehensive manner.For certain areas that still have the employment of technical personnel, who attended the training program of the center and has sufficient experience, implementation is still relatively good industrial relations. But for area minus the employment of technical personnel would be very disruptive and could impede the implementation of industrial relations. Looking ahead, employment technical training should be encouraged more quantity and quality so that shortage of technical personnel in the area of employment can be overcome. Second, the weakening of coordination between the agencies in charge of employment at district / city and the agency responsible for province-level employment. This happens due to the lack of structural relationship between the agency responsible for province-level employment.

In the system of self-government, government agency in charge of employment at the district / city is responsible to the regent / mayor, no longer to the government agency in charge of employment rate of the city, no longer to the government agency in charge of employment provincial level as a centralized government system. Program development activities and the development of industrial relations is often hampered just because of structural problems, their assumption that most of the agencies in charge of employment at the district / city is responsible to the regent / mayor so that the agency responsible for province-level employment should not be interfered with. This situation will be discussed in the LKS Tripartite provincial and district / city to look for solutions to the employment problem in the area can be handled professionally by the authorities echnical employment. In addition, governors, regents, mayors need to re-pay attention Circular of the Minister of Manpower and Transmigration No. 145.KP.01.12.2001 on Employee Utilization of Labor and Industrial Relations Intermediaries.

\section{THE ROLE OF GOVERNMENT ON AFFIRMATIVE ACTION}

Affirmative Action by Blacks Law Dictionary is "A set of actions designed to Eliminate existing and continuing discrimination, to remedy lingering effects of past discrimination, ad to create systems and Procedures to Prevent future discrimination". Initially in the form of affirmative action programs to equalize the rights of American citizens of African origin (black) become full US citizens. For the thirteenth constitutional amendment has declared that slavery is not valid; next Fourteenth Amendment guarantees equal protection under the law; and the Fifteenth Amendment which prohibits racial discrimination in selecting. In 1866 the Government issued the Civil Rights Act, which guarantees equal rights for every citizen to create and enforce a contract / agreement as well as is enjoyed by white citizens.Affirmative action then extends to employment, such as in terms of recruitment, precisely since 1941 when Roosevelt, signed an Executive Decree (Executive Order) 8802 which outlawed recruitment policy based on skin color by the contracting industry in terms of employment. The signing by President Roosevelt is the fruit of the work done by trade union leaders (black) A. Philip Randolph (Agusmidah, 2010: 288). Affirmative action is tantamount to giving the same opportunities (equal opportunities). In fact in recent decades of discrimination still occurs in every field, so Affirmative action still needed.Understanding the origin of affirmative action actually to eliminate discrimination, especially in terms of equal opportunity as citizens of the community, but would be expanded again in things that are more specific, such as measures to provide protection for the weak of action the parties are strong in one country. In this case the necessary affirmative action in the employment field although globalization has offered entry into force of the market mechanism in determining the amount of wages, flexible working system, a flexible rules for backing dismissed and the absence of severance rigid (Agusmidah, 2010: 289).

Reasons stated that affirmative action should be used by the government in the field of employment can not be separated from the fact that the bargaining position of workers / laborers even unions / labor is still not balanced because labor market conditions do not support the increase in the bargaining position of workers / laborers against employers. The demands of the market mechanism to the flexible work system the government must respond by setting clear boundaries so that the interests of workers / labor foremost is the welfare and social security is not neglected. In this case within the scope of welfare is a wage system that can guarantee a decent life to the worker / laborer. For example, the amount of basic wages, overtime pay, and so on. Medium which includes social security is the protection system in the form of health insurance are, severance and retirement funds for workers / laborers. The main objective of labor law is to eliminate the inequality of the relationship between multiple employers / entrepreneurs with workers / laborers, as in the preliminaries had been called by quoting the opinion Sinzheimer that in working relationships entrepreneurs are those who have more power than workers / laborers, even in terms of making the employment contract where there is the principle of individual freedom, but in reality this is only because the term of the employment contract worker / workers still do not have bargaining power to improve the working relationship Events desired.No.13 of 2006 , also found the prohibition of discrimination in the considerations that the protection of labor is intended to guarantee the basic rights of workers / laborers and ensure equality of opportunity and treatment without discrimination on any basis whatsoever for the welfare of workers / laborers and their families. In addition, Article 28 D Paragraph 1 of the Act of 1945 states that every person has the right to recognition, security, 
protection and legal certainty and equal treatment before the law ". (2) "Everyone has the right to work and to receive remuneration and fair and proper treatment in employment".

Indonesia is also bound by ILO Conventions recognized enforceability through ratification in national legislation. Most of the ratified conventions with regard to the principle of non-discrimination and protection of the rights of workers / laborers in the work place (work place). Thus the ILO Conventions can also be regarded as normative foundation for the state's role in matters of employment through affirmative action. Konveni ILO included in the category of international agreements of a general nature, the effectiveness of the ILO conventions should be approved. Act of ratification is one manifestation of such consent. So with the ratification of the ILO conventions, the obligation to carry out its mandate in the $\mathrm{CCW}$ is required, including by means of legislation relevant. Indonesia has ratified several ILO conventions that are related directly or indirectly by making labor agreement, are as follows:

1. The ILO Convention No. 98 of 1949 on the Right to Organize and negotiate Together, through Law No. 18 of 1956.

2. The ILO Convention No 100 of 1951 on the Granting Equal Wages To Workers Women \& Men for Work of Equal, through Law No 80 of 1957

3. The ILO Convention 106 of 1957 concerning Weekly Rest in Commerce Sectors and Offices, through Law No. 3 of 1961.

4. The ILO Convention No 144 of 1976 on Tripartite Consultation Through Improved International Standards Implementation of Presidential Decree 26 of 1990

5. The ILO Convention No. 87 of 1948 concerning Freedom of Association and Protection of the Right to Organize Through Presidential Decree No 83 On June 5, 1998

6. The ILO Convention No. 105 of 1957 concerning the Prohibition of Forced Labor, by Law No 19 of 1999

7. The ILO Convention No. 105 of 1957 concerning the Prohibition of Forced Labor, through the Law No.19 of 1999

8. The ILO Convention No. 138 of 1973 concerning the Minimum Age for Admission to Employment, through Law No.20 of 1999

9. The ILO Convention 111 of 1958 on the Prohibition of Discrimination in Respect of Employment and Occupation Through Law 21 of 1999

10. The ILO Convention 182 of 1999 on the Worst Forms of Child hiring, through Act 1 of 2000

11. The ILO Convention 88 of 1948 concerning Employment Service Agency Through Presidential Decree 36 of 2002

12. The ILO Convention 81 of 1947 on Labor Inspection in Industry Sector and the trade in Through Law No 21 of 2003

\section{REFERENCES}

[1]. M. D. Badrulzaman, Kompilasi Hukum Perikatan (Citra Aditya Bhakti, Bandung, 2001).

[2]. The Indonesia Civil Code

[3]. R. Khairandy, Itikad Baik Dalam Kebebasan Berkontrak (Program Pascasarjana FHUI, Jakarta, 2003).

[4]. Morton J. Horwtiz, The Transformation of American Law 1870-1960 The Crisis of Legal Orthodoxy (Oxford: Oxford University Press, 1992).

[5]. Atiyah, The Law of Contract (Clarendon Press, London, 1983).

[6]. H. Budiono, Ajaran Umum Hukum Perjanjian dan Penerapannya di Bidang Kenotariatan (Citra Aditya, Bandung, 2010).

[7]. H.F.A. Vollmar, Pengantar Studi Hukum Perdata, Jilid I, (Raja Grafindo Persada, Jakarta, 1996).

[8]. Z. A. K. Atmaja, Ed., Beberapa Yurisprudensi Perdata Yang Penting Serta Hubungan Ketentuan Hukum Acara Perdata, (Mahkamah Agung Republik Indonesia, Jakarta, 1992).

[9]. Peter de Cruz, A Modern Approach Comparative Law (Deventer, Kluwer, 1993).

[10]. Peters and Koesriani Siswosoebroto, Hukum dan Perkembangan Sosial Buku Teks Sosiologi Hukum Buku III, Editor A.A.G., (Sinar Harapan, Jakarta, 1990).

[11]. Law No. 13 of 2003 on Manpower

[12]. Hari Supriyanto, Perkembangan Hubungan Industrial di Indonesia, Justitia et Pax, 26 (2), 2006, 140-147

[13]. Circular of the Minister of Manpower and Transmigration No. 145.KP.01.12.2001 on Employee Utilization of Labor and Industrial Relations Intermediaries

[14]. Agusmidah, Dinamika Hukum Ketenagakerjaan Indonesia (USU Press, Medan, 2010). 